\title{
The Curse and the Chora:
} The Double-Bind of the Choraic Conduit in Angel and Penny Dreadful

\section{Kwasu D. Tembo}

\begin{abstract}
Referring to the work of Julia Kristeva, this article seeks to perform a comparative analysis between Cordelia Chase (Charisma Carpenter), as she appears within the remit of Joss Whedon and David Greenwalts's Angel (1999-2004), and Vanessa Ives (Eva Green) in John Logan's Penny Dreadful (2014-2016). Taking each character as a case study, this article seeks to elucidate the precarious subject positions of central female leads in a team/ensemble horror television series in order to assess whether or not and how the portrayal and characterisation thereof has changed over two decades. To do so, this article employs a theoretical framing that examines the question of agency and power by assessing both characters as what I will call "Choraic conduits". As such, both characters' relation, manipulation of by, and mediation of the supernatural as envisaged and presented in their respective diegetic worlds are analysed in themselves and comparatively against one another. Key concerns here are the questions and problems surrounding each character's agency over her powers and the supernatural/spiritual realm(s) from which they emerge, as well as the psycho-physical and symbolic consequences of not only the possession of their respective powers, but the micro and macroscopic consequences of how they are used in their respective diegetic worlds.
\end{abstract}

\section{Introduction: Cordelia, Vanessa, the Demi-monde and Double-Binds}

This article performs a close comparative reading of two lead female characters in ensemble horror TV shows, namely Angel's Cordelia Chase (1999-2004), created by Joss Whedom and Greenwalt David, played by Charisma Carpenter, and Penny Dreadful's (20142016) Vanessa Ives, created by John Logan, played by Eva Green. It draws attention to some interesting parallels in television narratives a decade apart. In particular, it analyses those parallels pertaining to the representation and characterisation of female leads in an ensemble horror TV cast who possess immense psycho-sexual powers that emerge from a Choraic interiority; that is, an Innenwelt of supra-ideological drives that are, in themselves, not necessarily subject to the phallogocentric and patriarchal rubric that seeks to control and exploit their expression and, through the control and exploitation thereof, their possessors.

Using Cordelia and Vanessa as case studies, this article will focus on theorising an overarching theme it will call the "Choraic conduit". This phrase refers to a prohibitive condition whereby the potent supernatural power each character possesses, which is inextricable from their respective sexualities, cannot be expressed outside or beyond the remit of the interests of the male characters it serves. Cordelia and Vanessa both possess the power within them to save or destroy their respective diegetic worlds, but are compelled by a narratological ideology that has persisted for the past decade to ensure they only reify that power in ways that serve, protect, advance, enlighten, and comfort the white male leads that surround them. Being that in each case this power 
is linked to the interruption of their respective sexualities and the pleasure in experiencing and expressing them beyond the phallic limits seeking to control them, the "Choraic conduit" subject position is also one necessarily predicated on a type of onto-existential (psycho-emotional and psycho-sexual) jouissance ruiné or ruined orgasm. The term "Chora", which I capitalise to emphasise the supra-ideological nature of the drives it contains, refers to a type of embodied psycho-emotional Innenwelt or interiority theorised by Julia Kristeva (Powers). For Kristeva, the Chora is a dynamic embodied space within an individual in which discrete quantities of energy move, mix, and play. According to Kristeva, this energy is, in its Choraic form, "free" up until it is expressed and subsequently (re)arranged semiologically through the various constraints imposed on the body through ideological apparatuses, and sociopolitical, economic, and cultural structures, primary of which is language.

My theoretical approach to Cordelia and Vanessa also gestures to the work of Barbara Creed. In The Monstrous-Feminine: Film, Feminism, Psychoanalysis, Creed inverts the typical relationship between horror and women that frames the latter as victims of a monster or monsters. Instead, Creed proposes a renewed analysis of this relationship where women are regarded as the monsters. In Creed's rereading, this relationship is an embodied one, whereby the relationship between physical states, bodily wastes (even ephemeral ones) and the horrific ultimately relate to the monstrous feminine. Particularly relevant to my discussion of the Choraic conduit is Creed's deconstruction of an often-discussed relationship between women, horror, and embodiedness inherent to the variety of stereotypes restricting the feminine, from virgin to whore, which ultimately seek to define women in terms of their sexuality.

This article also seeks to offer a few theoretical connections between the respective portrayals of Cordelia and Vanessa, and some of the specific elements identified by Lisa McLaughlin and Cynthia Carter. Both McLaughlin and Carter's work in their cofounded international journal Feminist Media Studies and cowritten book Current Perspectives in Feminist Media Studies identify themes of "media and identity" and "sexuality and sexualization" as key aspects of feminist media studies (McLaughlin and Carter 2-4). Across multiple interdisciplinary perspectives, these themes are engaged with in a variety of ways that seek to draw attention to the continual reductivist representation and (hyper)sexualisation of female characters in all media, both ostensibly and subtly. These analytical lodestars will be relevant for the ensuing discussion as it equally seeks to highlight how tenacious and surreptitious the reductive and hypersexualizing ethos can be in its manifestation in texts that are, by and large, regarded as feminist at the most, forward thinking at the least. In so doing, this article seeks to explore how each character contributes to these debates concerning the representation of female power(lessness), as well as the paradoxically exploitative valorisation of that power(lessness) in ensemble horror television of the past two decades.

My discussion of the monstrous feminine derives from Creed's work on the relationship between femininity and abjection, which owes much to Kristeva's work on the same topics set out in her pioneering 1982 work Powers of Horror: An Essay on Abjection. For Kristeva, the issues and debates surrounding abjection in and on the border of onto-existential experience, the motherchild relationship, and the feminine body, are predicated on the idea that "definitions of the monstrous as constructed in the modern horror text are grounded in ancient religious and historical notions of abjection [...] perversion, corporeal alteration, decay and death, human sacrifice, 
murder, the corpse, bodily wastes, the feminine body, and incest" (Powers 93). In Kristevan terms, the abject is also pregnant with concepts including but not limited to the liminality of interstitial onto-existentialism, and post-identarian approaches to questions of the self, selfhood, and subjectivity more broadly. As Kristeva puts it, the abject is, both abstractly and concretely through the lived experiences of the body, "the place where meaning collapses", the place where "I am not" (Powers 3).

Based on a primarily Creed-Kristevan understanding of the relationship between the abject and the feminine/female, this article maintains that even though the "horror text" and its various thematic and intermedial configurations have altered in some respects since 1982, significant aspects of the relationship between horror and the feminine/female remain founded on the abject/abjection. The extreme implication of this assertion is that horror itself as a genre, along with its subgenres, is one of abjection, informed by abjection. While Creed and Kristeva outline numerous categories in which the abject and the feminine/female encounter one another, the concept of "The Woman as Possessed Monster" in particular bears most heavily on my analysis of Cordelia and Vanessa as Choraic conduits.

\section{The (Un)Familiar: A Contextual Overview of Angel, Penny Dreadful and the Genre of Horror TV}

This article acknowledges the extensive discussions that have already taken place on TV horror as a specifically recognised genre, a particularly noteworthy example in this body of scholarship being Lorna Jowett and Stacey Abbott's seminal 2013 text TV Horror: Investigating the Dark Side of the Small Screen. While TV horror may be a vastly more commonplace part of global visual and pop cultural content, this article recognises the fact that the genre (and its subsequent subgenres) were, at the time of the original broadcast of Angel, a contentious issue. The two texts under comparison here are separated by two decades in which many sociopolitical, economic, cultural, and media changes have occurred. It was over this period of time that TV horror was debated, discussed, and finally accepted as a genre. Penny Dreadful aired a decade after the conclusion of Angel, and between those two successive finales, there have necessarily been pronounced differences in viewing methods related to networks/streaming that have undoubtedly (further) affected what can be shown as "TV horror". Scholars including Anne Hill and Ian Calcutt have not only commented on criticism querying Angel as an example of TV horror, but also how the show itself, and TV horror more broadly in the UK, was effected by the British scheduling and viewing experience of Angel as broadcast/syndicated media.

One could offer a more nuanced argument concerning the similitude of medium and message as Benjamin Poore does. Poore asserts that the contemporary viewing experience of Penny Dreadful operates "in the same way that penny fiction created new modes of consumption, the new television shows drawn from the HBO template 'introduced a new form of television viewing' where whole seasons could be consumed as DVD box sets, or as 'virtual' box sets via Netflix or digital video recorders" (69). This is another aspect of the demi-monde ethic pervading the show to which Poore draws attention, stating that "Penny dreadful' also, of course, makes explicit the fine balance struck between art and commerce: the penny price of the Victorian serial and, in a less visible way, the monetary investment in a cable TV subscription for exclusive 
content. First give us your penny, and we will show you something dreadful" (77). Inherent to the show's evocative promise (and indeed delivery) of violence and sex through its high conceptualisation of horror is the notion that the libidinal expressions of the radical play and power of the Chora are ultimately loosed in order to entice, seduce, and titillate an eager viewership, not express the onto-existential potential inherent to said expressions, hidden or veiled under the familiar repressiveness and indeed appeal of the Choraically nullified and contained female figure.

In terms of the double-binding of antipodal subject positions acting on female characters in ensemble horror TV shows, Sherryl Vint draws attention to how Cordelia goes from the selfcentred rich mean-girl obsessed with her physical attractiveness and its power to garner male attention in Buffy to the supernaturally endowed, strong, mature, and responsible working-class business manager of Angel Investigations in Angel. In view of this dichotomy, Vint posits that "Cordelia's character was redeemed [in Angel]", a confirmation of progress, development, and maturation resulting from this transition (189). However, while audiences may have felt that Cordelia "grew" throughout Angel, she did not outgrow the underlying antipodal tension inherent to the Choraic conduit which persists within the ostensibly emancipatory thematic milieu of the series. The danger here is that, in this subtle and indeed alluring and ostensibly progressive expression of feminist ideals, the framing, voicing, and presentation of characters like Vanessa and Cordelia redounds to a form of palliative feminism for an aging patriarchy. Here, Vint calls for a re-examination of the double-bind of female power expressed as ostensibly emancipatory and progressive, how specifically male auteurs and writers like Logan and Whedon "might push us toward evaluating how a certain kind of feminism can still be palatable to patriarchy, whereas other kinds of strong female characters remain pathologies" (180-1).

Since Buffy the question remains: despite these thematic, aesthetic, and generic experiments and repackagings, has either Angel or Penny Dreadful in fact achieved anything new? Despite Eva Green's searing performance and Logan's emphatic writing, there is a sense of underlying familiarity to the character and, in spite of the veneer of radical revisionism, Penny Dreadful does nothing new with arguably its most important character. As Poore notes, the series emerges from the shadow of notable (in some instances infamous) intermedial precedents. The concept of a team of Victorian antiheroes who unite to battle the forces of darkness, some with supernatural abilities, is taken straight from the lauded pages of Alan Moore and Kevin O'Neill's graphic novel series The League of Extraordinary Gentlemen (1999-2019) and its lambasted 2003 film adaptation by Stephen Norrington. Like Moore and O'Neill's conceptualisation, Logan's team is morally and ethically opaque and changeable, albeit also familiar in their conforming to the fractured, unconventional family trope common in both ensemble television and horror more specifically. Sir Malcolm, the patriarch, acts as benefactor and surrogate to both Vanessa and Mina, her childhood companion. Throughout the series, Ethan Chandler (Josh Hartnet) and Victor Frankenstein (Harry Treadaway) often appear to occupy the roles of wayward sons. Similarly, Ferdinand Lyle (Simon Russell Beale) can be regarded as an eccentric uncle. Therefore, "there is a hint", asserts Poore, "in this semi-domesticated Gothic, of the classic 1960s US situation comedies The Munsters and, in particular, The Addams Family, with Vanessa Ives as a bewitching Morticia and Sir Malcolm Murray a solemn, angst-ridden Gomez" (67). In this sense, the sensuality and dark appeal of Morticia is a trope Vanessa works/exists both in and against.

However, it is paradoxically precisely through its new characters-including Vanessa- 
that the series is able to ostensibly offer something new in terms of both horror TV and gender studies. According to Poore, the new characters Logan introduces-Vanessa Ives, Ethan Chandler, Brona Croft (Billie Piper), Sir Malcom (Timothy Dalton), and Sembene (Danny Sapani) —all, in their respective engagements and expressions of horror and the supernatural, offer the series several avenues through which to offer incisive observations and cultural criticism of the nineteenth century from the vantage of twenty-first century hindsight (73). For example, while demonically possessed in Season 1, Episode 7 ("Possession"), Vanessa, offers a scathing critique of the latency of Sir Malcom's imperialist doxa and the overarching colonial machinations of his so-called civilising interventions in Africa. Pertaining specifically to herself, Vanessa draws attention to the latently misogynistic undercurrent of Victorian society in toto: "to be beautiful is to be almost dead, isn't it? The lassitude of the perfect woman, the languid ease, the obeisance" (Logan, "Possession"). Despite these and other moments of sociopolitical critique and insight that make the show, and in particular its portrayal of its female characters and their embodied (physical and spiritual alike) expressions of agency as progressive, that sense of progressiveness is still problematically bound in a dichotomous framework (Poore 73-4). It is precisely in the midst of this deconstructive move that Logan simultaneously reinscribes Vanessa in the violent dichotomy of the horror trope of the Choraic conduit; ultimately, a subject position that is necessarily selfantagonistic, in part referring to constraint and exploitation, while also referring to radical play. While Vanessa might not be a classic Gothic hysteric or fallen woman, her status as a Choraic conduit places her in a position to still be an appetitive object of and for male possession and exploitation. She might seem an anti-Mina Murray (Olivia Llewellyn), that is capable, aware, powerful, complex and seemingly unbound from the conventions of demurity and restraint that mark Mina's passivity. However, their respectively undifferentiated statuses as potential concubines for a dark lord, be it Dracula, Satan, or both, is a fate both ultimately share.

\section{The Choraic Conduit as Good/Bad Pleasure, or Power (Un)Bound}

A comparative reading of Vanessa and Cordelia reveals that the Choriac conduit is, in many ways, cursed to endure or experience the power of her pleasure outside of male agency or its enabling as a type of self-annihilating "bad pleasure". This raises the questions of the relationship between so-called "good pleasure" or "correct pleasure" (the Choraic-conduit-as-pleasurecontained), contra so-called "bad pleasure" (the unbounded flows of Choraic power) (Gaines 86). For Merri Lisa Johnson, "those 'lures and pleasures' recall an unresolved debate in feminism over the politics of pleasure: the problem of bad pleasures lurking and lulling women into false consciousness, complicity with patriarchy, masochistic submission" (395). The relationship between reductivism and female pleasure as having no "valid" or "legitimate" outlets save through self-capitulating means is also taken up by Catherine MacKinnon, who asserts that "[m]asochism insures that pleasure in violation defines women's sexuality, so women lust after self-annihilation" (42).

One way Penny Dreadful is said to represent progress in terms of horror TV pertains to the show's engagement with sex. Much has been made of the show's explicit, and to some valorising, treatment of sex and sexuality. Scholars including Kristina Busse and Karen Hellekson have suggested that the show takes full advantage of shifting Western sexual mores in recent years, and the general relaxation of anxiety surrounding sexual explicitness in both heterosexual and 
nonheterosexual manifestations (16). However, this may not be either as novel or revolutionary as initially appears. On the one hand, the show focusses on abject individuals: orphans, runaways, outlaws, and the psycho-emotionally and spiritually wayward in a way Poore describes "as a valorisation of outsiderdom (be that sexual, intellectual, or social)" (75). On the other hand, the notion that the sexually explicit handling of outsider characters is revolutionary is, by itself, insufficient to warrant the accolade (76).

Stephanie Green also notes that, in his portrayal of women, particularly the central leads Vanessa and Lily/Brona (Billie Piper) from the second season onward, Logan's women, including Evelyn Poole (Helen McCory) and Hecate Poole (Sarah Greene), are depicted as capable agents of transformation through creation and destruction beyond the remit of Victorian convention. They seek autonomy in various forms, and express it through intellect, sexuality, and ambition. Green refers to these expressions of power as "compromised power, inflected with darkness, uncertainty and threat", noting how the women of the series are-or become-

able to wreak supernatural forces, with powers to defend themselves and/or to control and recruit others. Their potency is, at the same time, limited by their relationship with more powerful male figures in their lives, whether human or inhuman [...] Although in Seasons One and Two, Vanessa resists dominance by the same satanic figure who seeks to embrace and control her powers, she is consistently depicted as a figure of suffering resistance and recovery. In Season Three [...] she is ultimately portrayed as an acquiescent victim, rather than as an effectual force for good in the world. (4-5).

In this way, the antipodal arrangement of the Choraic conduit pertains to but also paradoxically restrains and propels Vanessa, Lily, and other female characters' arcs. It achieves this static motion in ways Green asserts "seem to be little more than adaptive ways of telling the old story in which the Gothic New Woman must be contained. At the same time, they promise more: whether through sacrifice, determination, strategy, or even through emotional connection" (12-13). On the one hand, postfeminist portrayals of women in media often present female characters as agents of power who are able to express that power independently of ideological stricture that seeks to either reduce their desires or justify/validate their desires only as tributary to the purposes of conventional heteronormative romance. "With Vanessa Ives," notes Green, "Penny Dreadful show[s] us a similar reframing of the late nineteenth century female persona, as women in possession of autonomy, desire and a personal or supernatural potency that enables them to overcome resistance to male authority and societal expectation" (13). On the other hand, the theme of reductive sequestration of female power is explored in Penny Dreadful through "its various scenes of female entrapment, for example when Vanessa Ives is locked in a Victorian madhouse because of her visions" (6).

In Angel, one of the most troubling manifestations of this psycho-sexual and supernatural negotiation for Cordelia is the fact that, throughout the series, she is unable to consummate her love for either Angel or the Groosalugg (Mark Lutz), a half-demon champion from an extradimensional kingdom called Pylea introduced in Season 2, Episode 21 ("Through the Looking Glass"). Despite growing increasingly closer with Angel throughout the show's five seasons, Cordelia is unable to have sex with him due to the fact that, as part of the latter's quest for redemption, the Gypsies who cursed him by "reinsouling" him did so with a specific proviso: if 
Angel experiences a moment of true happiness, he reverts back to his deviously soulless and wildly murderous alter ego Angelus. The curse is characterised as Angel having an orgasm with someone he truly loves (indirectly making Angel himself a Choraic conduit as well in being mystically cut off from any shared experience of true-pleasure-in-true love at the risk of the emergence of destructive, uncontrollable evil). In the end, however, the only way Angel and Cordelia are allowed to consummate their love is virtually, that is, through a hyperreal vision created and administered directly into Angel's subconscious by a shaman in Season 4, Episode 10 (“Awakening”). The key aspect of this virtual sex scene to note is that it takes place entirely in Angel's subconscious. Thus, whatever sense of pleasure, connection, or simply relief derived in this simulacral encounter is absolutely one-sided: her experience of reified desire, with and through Angel, is always-also prohibited and withdrawn by the details of his own narrative.

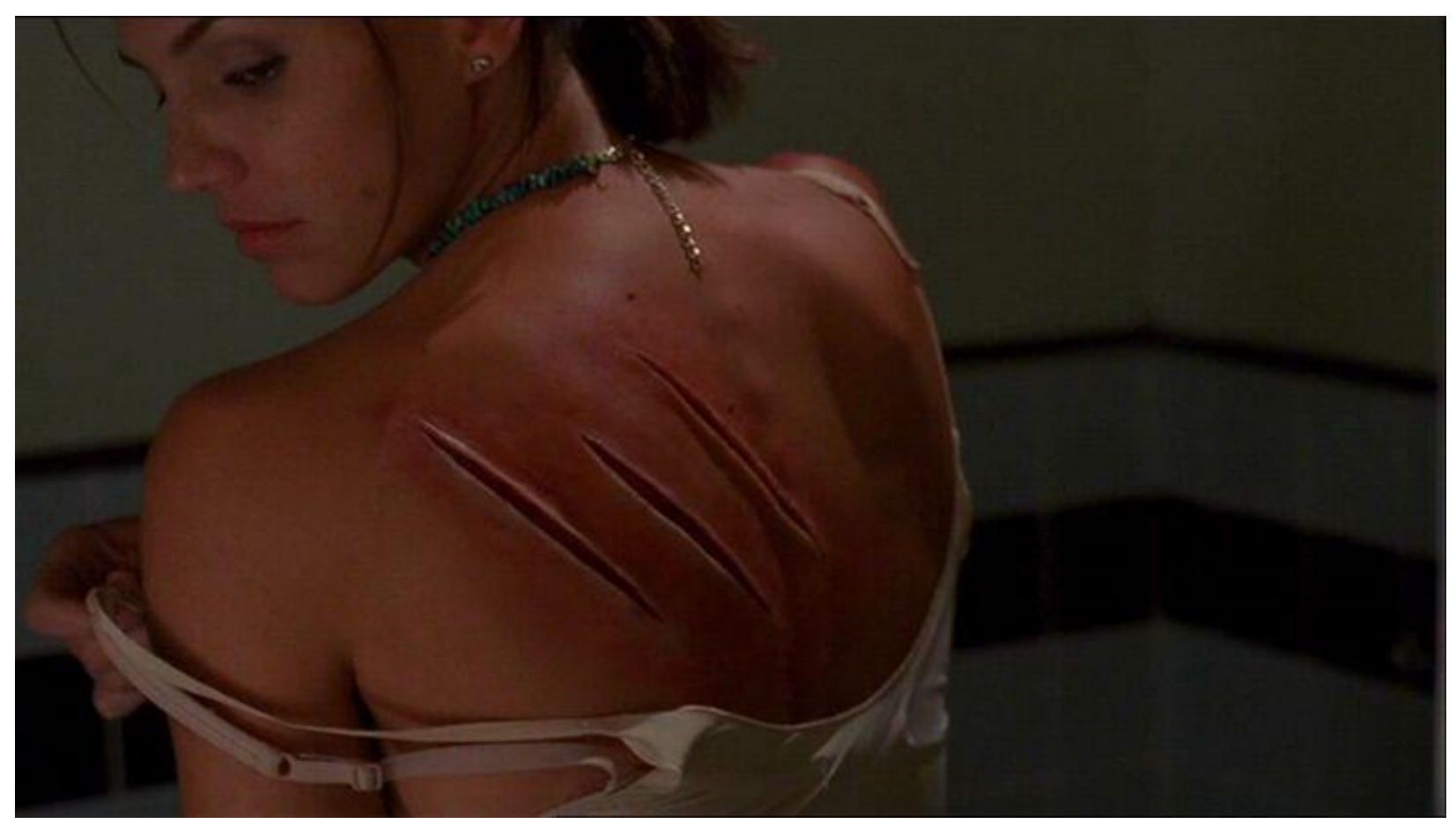

Figure 1: Clawed within and without: the price of Cordelia's "visionity". Screenshot.

With the Groosalugg, it is revealed at the end of "Through the Looking Glass" that Cordelia is made regent of Pylea due to her precognitive visions. However, in Season 2, Episode 22 ("There's No Place Like Plrtz Glrb"), Cordelia becomes aware that Pylea's version of the evil interdimensional law firm Wolfram and Hart seeks to use the Groosalugg to strip Cordelia of her visions (what she refers to as her "visionity") through ritual sex called "the royal comshuk". If consummated, Cordelia learns that she will lose her visions, her direct connection to The Powers That Be, and therefore any direct supernatural link between demons and her body. In this way, Cordelia is cursed to suffer not only her visions but also a mystico-sexual chastity in multiple ways, lest she risk the sovereignty of her "visionity" and, therefore, her central role, purpose, and sense of self and self-worth within the pseudo-familial structure of Angel Investigations. While this means that Cordelia maintains a kind of "purity" through celibate martyrdom, it is ultimately a cursed purity. 
In Penny Dreadful, Vanessa finds herself in a not altogether dissimilar predicament. While Lauren Rocha states that, in framing the series' main characters as urban monsters, the show provides a nonhuman perspective through which to examine societal constructs of gender in relation to selfhood, Poore notes that "Gothic writing always concerns itself with boundaries and their instabilities, whether between the quick/the dead, eros/thanatos, pain/pleasure, 'real'/'unreal', 'natural'/'supernatural', and it is precisely this imaginative space that Penny Dreadful seeks to occupy" (77). It is this space that Vanessa most stringently occupies and is ostensibly liberated in but latently enveloped in. Vanessa's position as a Choraic conduit represents the theme of the demi-monde (I go as far as to call Vanessa a "demimondeur") pervading the show. As Vanessa asks Ethan on their first meeting: "Do you believe there is a demi-monde, Mr Chandler? A halfworld between what we know and what we fear?" (Logan, "Fresh Hell"). Vanessa both literally and figuratively straddles this divide, is drawn to it in ways that ultimately and paradoxically speak or call to her Choraic power, but also seek to bind it at the same time. While Vanessa suffers visions and possessions, and despite the psycho-emotional and spiritual turmoil she endures, she attempts to use her suffering to help her surrogate father Sir Malcolm. In this way, through Vanessa's status as a Choraic conduit, Penny Dreadful emphasises the double-bind thereof: female agency/female servitude, female suffering/female helpfulness, and female sexuality/female danger.

Throughout the series, Vanessa's body is coded as an abject site of demonic sexuality, a body that exists on the radical border between what Kristeva refers to as "the clean and proper body' and the abject body, or the body which has lost its form" (Creed 11). She cannot control it fully, and its power, seductiveness, and the pleasure she derives from it make it equally undeniable. Unlike Cordelia's instructional visions, which are dangerous and often painful, the didactic aspects of Vanessa's fits or visions are limited at best. Cordelia's visions are didactic/apparatus of male character's journey as in Season 5, Episode 12 ("You're Welcome") in which Cordelia, having mystically arisen from her pregnancy-induced coma for one final day before dying, functions as Angel's psychopomp one more time. When asked by Angel in private why the Powers woke her, Cordelia herself declares that the sole (and indeed soul) purpose of her return was to help "get him back on track" and, more directly, pass on a strategically imperative vision concerning how to effectively challenge the Senior Partners of Wolfram and Hart. In this sense, her status as a Choraic conduit is crystallised in said kiss: the moment of somewhat consummation of their attraction is, in fact, a means of service to Angel's narrative whereby Cordelia's pleasure is ultimately little more than a vector of a monumentally important transference of power from female to male. It is upon this vision that the second and final half of the series' final season depends.

Vanessa's abjection becomes less an apparatus of a male character's journey toward redemption, one predicated on the suffering, labour, and forbearance of she who suffers the Sight, but a deeply personal and idiosyncratic phenomenon. In Season 3, Episode 4 ("A Blade of Grass"), Vanessa's cursed Sight, the seat of her sexuality, is targeted by Lucifer and Dracula. In each instance, while the bearer of what is gradually portrayed as apocalyptic sin might not understand the power and consequences of what she carries/has access to, Lucifer and Dracula, two archfiends of ecclesiastic and Gothic literature, seek it for themselves for the purposes of revenge and deicide in the former, and apocalyptic dominion of the Earth in the latter. However, this power cannot be taken from Vanessa. It has to be freely given, a conundrum portrayed as Vanessa being proposed to by Lucifer and Dracula. More fundamental to these red overtures from these dark lords is the 
fact of Vanessa's power and its inextricable link to her sexuality, which is portrayed as a latent, immovable danger. As Rocha notes,

at best, [this] danger can be temporarily delayed [...] During a sexual encounter, Vanessa unleashes the demon inside her and in doing so, allows it to possess her. The incident, however, is not isolated as she carries the demon inside her at all times; her so-called "fits" are brought on by 'emotion of some kind' which is sexual in nature.

Rocha further notes how Vanessa experiences possession as a type of way-making. When possessed, Vanessa becomes a supernatural doorway or portal through which the quotidian world and the demi-monde - the half-world between what one sees and what one fears-come together. Moreover, when possessed, the demon always threatens to transform Vanessa into the apocalyptic force known as the "Mother of Demons". For Vanessa, the demon's manifestation through possession is inextricable from her attempts at sexual expression. Not only does the demon seek to exploit and figuratively and literally possess her reproductive ability in these moments, doing so also overtly emphasises the gendering of her body and its powers. Rocha further notes:

Condemned for her sexuality, the demon could also be called [Vanessa's] sexual desire; controlled, it does not pose a threat, but when it takes over, she becomes dangerous to those around her, especially men. All the while, she continues to fight it inside her, struggling to regain control of it. She confesses, "You don't know what it's like having this thing inside me. This [...] scratching. That's an awful word, but that's what it feels like. An animal scratching to get out".

In the last instance, despite two decades separating them, as Choriac conduits, both Cordelia and Vanessa are identically cursed to suffer their unexpressed sexualities as well as the psychoemotional and physical burden of their abilities in arrangements that make each mutually exclusive to one another.

\section{Visionity, Black Ekstasis, and The Choraic Conduit}

My development of the idea of the "Choraic conduit" is indebted to Kristeva's concept of the Chora. In "Revolution in Poetic Language", Kristeva describes the structuring of the human body as follows:

Discrete quantities of energy move through the body of the subject who is not yet constituted as such and, in the course of his development, they are arranged according to the various constrains imposed on this body-always already involved in a semiotic process-by family and social structures. In this way the drives, which are "energy" charges as well as "psychical" marks, articulate what we call a chora: a non-expressive totality formed by the drives and their stasis in a motility that is as full of movement as it is regulated ("Revolution" 2072).

While Kristeva uses the term Chora as a means of identifying and denoting "an essentially mobile and extremely provisional articulation constituted by movements and their ephemeral stases", my 
usage of the term isolates the notion of the power and chaos of the energy or energies that exist beneath the over-arching superimposition of the power of ideology, including its predicate phenomena namely the concept of self and its dialectical opposition to the Other ("Revolution" 2073). When applied to Cordelia and Vanessa, their psycho-sexual interfacing with the supernatural produces an inherent destabilisation of the dialectic of self/Other. Here, Cordelia's "visionity" and Vanessa's "black ekstasis" are fundamentally Choraic, both primordial unities of undifferentiated drives, including human drives and supernatural drives.

Vanessa's Choraic power is portrayed and depicted in dichotomous ways, as a type of "dark ekstasis" on the one hand, and as abjectly consumptive on the other. The former is most powerfully depicted in Season 1, Episode 6 ("What Death Can Join Together"), where Vanessa and Dorian's sexual encounter, shot in delirious, enticing, pseudo-nauseating slow-motion long exposure, in which Vanessa's face, captured in candlelight, bears the eye-rolled look of deep mind and soul-bending ecstasy. Her "black ekstasis" is shown to warp reality, undo time in its hypersensuality. The horrific element in the aesthetic rendering of this scene emerges through the seductive, triumphant, quietly domineering, and possessive voice greeting her in her mind midcoitus, one that seduces her to a type of onto-existential fall. The result of this union is full demonic possession. In the following episode, Season 1, Episode 7 ("Possession"), Vanessa's physical condition deteriorates, leaves her pale, emaciated, riddled with cuts and wounds. On the brink of death, she requests that she be given her last rites before being put out of her misery with a kindly bullet. However, Ethan performs a successful exorcism, freeing her of the demon's hold. So, while the series portrays Vanessa as the actualiser of her Choraic power as she "seeks to triumph over supernatural evil and liberate herself from the clutches of the dark master", the psycho-emotional and physical manifestations of the violence of this struggle are problematically paradoxical. On the one hand, they are shown to leave Vanessa bed-ridden and keenly on the brink of death. On the other hand, they glamorise her suffering, presenting the process of possession as so deep and passionate as to be worth any and all risks that result therefrom (Green 10). These two episodes represent one of numerous instances in the series that show how

the female characters struggle with the attempt to seek empowerment, whether caused by enchantment, witches and demons that seek to inhabit their minds, or by institutional incursions and restraints. In the scenes in which Vanessa Ives is trapped in one way or another by possession, hallucination, or memory, her thin white body is marked brutally by her sufferings, and her shadow eyes are particularly haunting. Vanessa alludes to her position as a woman whose truth is unable to be heard (3.04); instead she is subjected to the institutionalized discipline of silence and conformity (Green 12).

Despite, and indeed magnified by, her emaciated, malnourished, and consumptive physicality, Vanessa's agony is aestheticized in such a way that portrays it as a type of sexual ecstasy, the same double bind repeats in the series' second season. In Season 2, Episode 7 ("Little Scorpion"), Vanessa and Ethan begin an intimate encounter but, realising the potential danger, Vanessa ceases foreplay before having sex or climaxing. Later, the force of this jouissance ruiné manifests in a latently masturbatory scene in which Vanessa reads from a powerful occult text known as the Verbis Diablo, causing her to possess a dog and through it, brutally maul a man to death. Even the indirect and overtly onanistic expressions of Choraic sexuality are presented as horrific, awful, violent, and latently "obscenely limitless" in the suggestion of a type of psycho-sexual bestiality. 


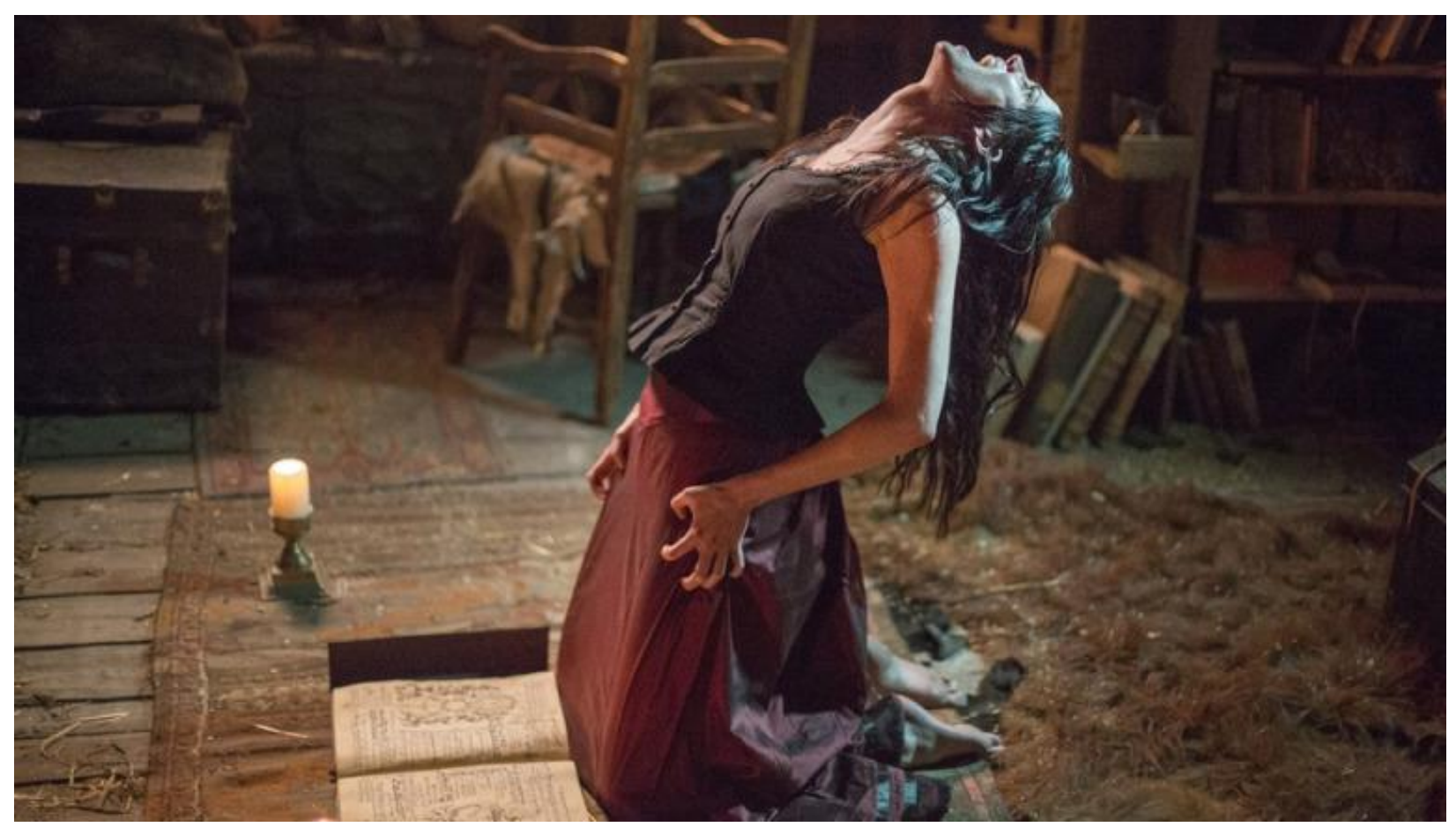

Figure 2: Vanessa and the black ekstasis of being struck by the back-hand of God. Screenshot.

Implicit in the characterisation of "visionity" and "black ekstasis" in their respective aesthetico-narratological contexts, is the essential link between access to the undifferentiated primordial forces of the Chora, and horror, terror, suffering, and pain. I concede that the manifestation of these powers can sometimes appear surreal or beautiful, such as when it is revealed that following Cordelia's ascension to the Higher Plane at the end of Season 3, she transformed, and was granted yet further powers, being able to cleanse evil influence in and around individuals and objects with a white glowing light ("Tomorrow"). For Vanessa, the dark beauty and Choraic intensity of the scene in Season 1, Episode 7 ("Possession"), in which she allows the "black ekstasis" to possess her, is portrayed through multiple exposure and extreme slow motion, as if to suggest that Vanessa becomes simultaneously both multiform and total in zeniths/nadirs of her Choraic power. It is an aesthetic choice by episode director James Hawes that emphasises not only the liminal space between bodies in the scene, but the broader and more abstract chronotopal liminality afforded/suffered by Vanessa as a result of "the demon". In each instance, brightness and suspended time are devices used to represent the unrepresentable, the fusion of all being into a primordial Oneness or Wholeness at the core of the Chora.

However attractive the aesthetic used in these two instances, the preponderance of other instances in both series where sexuality and the supernatural collide are aesthetically represented as painful, disturbing, terrifying, horrific, and awful. In this way, both Cordelia and Vanessa's "visionity" and "black ekstasis" as suffering a type of paradoxical painful pleasure, can be thought of on terms of the psychoanalytic concept of jouissance first developed by Jacques Lacan. In Powers of Horror, Kristeva refers to the experience of jouissance as a phenomenon that "jettisons the object into an abominable real, inaccessible except through jouissance. It follows that jouissance alone causes the abject to exist as such. One does not know it, one does not desire it, one joys in it [on enjouit]. Violently and painfully. A passion" (Powers 9). The paradoxical nature 
of jouissance, an experience that compels the subject to submit to it through said experience, is predicated on the idea that fascination of the subject with the abject is one of both attraction and repulsion, manifests interestingly and tragically for Cordelia and Vanessa. As John Clare, a.k.a. Caliban, a.k.a. Victor's Creature says to Vanessa in Season 2, Episode 9 (“And Hell Itself My Only Foe"), "true evil is, above all things, seductive. When the Devil knocks at your door, he doesn't have cloven hooves. He is beautiful, and offers you your heart's desire in whispered airs. Like a siren, beckoning you to ruinous shore."

Cordelia is simultaneously fascinated by the internal sources of her abjection, namely her suffering demonic powers in her body, but also external sources of her abjection such as Angel and the Groosalugg. While Cordelia is ostensibly attracted to each, she is simultaneously repulsed by them, Angel's gory past as a soulless child-murdering and nun-raping mass murderer, and the Groosalugg as an interdimensional being whose sole purpose in encountering her was to strip her of the very same abjection that gives her life meaning and purpose. For Vanessa, all the individuals she is attracted to, the American sharpshooter/wolfman Ethan Chandler, the immortal libertine Dorian Gray (Reeve Carney), and quietly undeniable Dr. Sweet/Dracula (Christian Camargo), are all marked by their own supernatural abjections that she ultimately does (and would, should she be privy to it, being for the entirety of the show unaware of Dorian's curse) find repulsive because they drag her back to the inescapable fact that her sexuality is linked to darkness and is, potentially if given over to Lucifer or Dracula, apocalyptic. In this way, "jouissance demands an abjection from which identity becomes absent" a death of self, a limit-experience where one is as far from oneself while still being one self, the cost of which is ultimately the potential death of others (Kristeva, "Revolution" 54).

In view of the series' preoccupation with mediumship, corpses, and possession, the notion of the Conduit, the embodied channel, the personified pyxis (as in the container of Powers opened by Pandora), and a tool not only suit the show's Gothic framework, but also serve to frame Vanessa's expressions of power (Poore 69). That said, this exorbitancy of psycho-sexuality and pain/suffering is, in every furtive glance, brush of hands, or kiss, latently always-already gesturing to a collapse back into the idea of primordial Oneness, into the Chora, into undifferentiation, selflessness, Monadism, the self into the Other, the self-Other assemblage through sexual connection. The implication here is that sexuality, as the source of both characters' respective greatest weaknesses, is also a source of their greatest strengths and, especially with Vanessa, the source of her dark lustre, which Lucifer and Dracula see as a conduit/Event/catalyst for the dissolution and domination of all selves in toto, if unleashed. I argue that it is the connection to the undifferentiated Choraic forces Cordelia and Vanessa have access to through their supernatural sexuality that makes each an example of transgressive, identarian, onto-existential, and psychoemotional power. In this way, included in the theoretical content of the Choraic conduit caused by sexuo-supernatural interfacing is the primordial flow of life, death, and rebirth.

\section{Conclusion}

Among other things, Johanna Dorer and Brigitte Hipfls's article on "Current Perspectives and Future Challenges in Feminism and Media Studies" offers a broad purview of the history of feminism in its sociopolitical, economic, historic, and cultural permutations. It draws attention to 
specific scholars in this field to speculate as to the various directions the multiple discourses in feminist media studies may tend toward in the future. An interesting example in this regard is Angela McRobbie's study "Aftermath of Feminism" in which the author demonstrates how feminist concepts are at worst denatured, at best transformed by popular media and broader media formats to better conform to the teleology of neoliberal projects, specifically the praxes that substantiate and subtend contemporary consumer culture. According to McRobbie, these acts of transmutation are predicated on self-disciplining measures which employ psycho-physical and emotional praxes of discipline and punishment masquerading as agency. In this way, the emancipatory and egalitarian ideals of feminism are inverted into their opposites (McRobbie 68).

Has this insidiously contrapuntal phenomena and praxis altered since the publication of McRobbie's text? Looking at Cordelia and Vanessa, what has changed? Not much, as in each case, what occurs is the transmutation of a radically emancipatory, dangerous, and supra-moral force of power, of Choraic energy and impulses, into a curse or an appetitive feature of a female character's serviceability in aiding the white male protagonist on his quest of self-actualisation. The latter of which cannot occur without the subjugation of the female characters' power(s), regardless of how amicably, ostensibly equally, or voluntarily it may appear. In this sense, the female characters' participation in both ensembles, and their respective places therein, though interesting, myriad, nuanced, complex, and ostensibly honest still maintain a problematic, antifeminist substrate in their representation; namely, in the last instance, that representation still adheres to the subjugative contours of servitude, submission, self-criticism/hatred/disgust, and a false self-consciousness wherein which power becomes thought of as a curse at worst, a means of service and/or attaining use value at best (which, in many ways is worse). In the last instance of both series, the worldending power possessed by each female character is yoked to sexuality.

\section{References}

“A Blade of Grass." Penny Dreadful, Season 3, Episode 4, written by John Logan, directed by Toa Fraser, Showtime, 2016.

“And Hell Itself My Only Foe." Penny Dreadful, Season 2, Episode 9, written by John Logan, directed by Brian Kirk, Showtime, 2014.

“Awakening." Angel, Season 4, Episode 10, written by Steven S. DeKnight, directed by James A. Contner, Warner Brothers, 2003.

Busse, Kristina, and Karen Hellekson, editors. The Fan Fiction Studies Reader. U of Iowa P, 2014.

Creed, Barbara. The Monstrous-Feminine: Film, Feminism, Psychoanalysis. Routledge, 1993.

Dorer, Johanna, and Brigitte Hipfl. "Current Perspectives and Future Challenges in Feminism and Media Studies." International Journal of Media and Cultural Politics, vol. 9, no. 3, 2013, pp. 305-13, DOI: https://doi.org/10.1386/macp.9.3.305_3. 
Gaines, Jane. "Women and Representation: Can We Enjoy Alternative Pleasure?" Issues in Feminist Film Criticism, edited by Patricia Erens, Indiana UP, 1990.

Green, Stephanie. "Lily Frankenstein: The Gothic New Woman in Penny Dreadful." Refractory: A Journal of Entertainment Media, vol. 28, 2017, refractory.unimelb.edu.au/2017/06/14/green. Accessed 15 Aug. 2020.

"Good and Evil Braided Be". Penny Dreadful, written by John Logan, directed by Damon Thomas, Showtime, 2016.

Hill, Anne, and Ian Calcutt. "Vampire Hunters: The Scheduling and Reception of Buffy the Vampire Slayer and Angel in the United Kingdom." Undead TV: Essays on Buffy the Vampire Slayer, edited by Lisa Parks and Elana Levine, Duke UP, 2007, pp. 43-56.

Johnson, Merri Lisa. "Ladies Love Your Box: The Rhetoric of Pleasure and Danger in Feminist Television Studies." Media/Cultural Studies: Critical Approaches, edited by Rhonda Hammer and Douglas Kellner, Peter Lang, 2009, pp. 392-411.

Jowett, Lorna, and Stacey Abbott. TV Horror: Investigating the Dark Side of the Small Screen. I. B. Tauris, 2013.

Kristeva, Julia. "From Revolution in Poetic Language, Part I, The Semiotic and the Symbolic." The Norton Anthology of Theory and Criticism, edited by Vincent B. Leitch, W. W. Norton \& Company, Inc., 1984, pp. 2067-81.

---. Powers of Horror: An Essay on Abjection. 1982. Translated by Louis-Ferdinand Céline, Columbia UP, 2006.

Lacan, Jacques. Le Séminaire. Livre IV. La relation d'objet, 1956-57. Seuil, 1994.

League of Extraordinary Gentlemen. Directed by Stephen Norrington, 20 ${ }^{\text {th }}$ Century Fox, 2003.

MacKinnon, Catherine A. "Pleasure Under Patriarchy." Sexuality and Gender, edited by Christine L. Williams and Arlene Stein, Blackwell, 2002, pp. 33-43.

McLaughlin, Lisa, and Cynthia Carter, editors. Current Perspectives in Feminist Media Studies. 2013. Routledge, 2018.

McRobbie, Angela. The Aftermath of Feminism: Gender, Culture and Social Change. Thousand Oaks, Sage, 2008.

Moore, Alan, and Kevin O'Neill. The League of Extraordinary Gentlemen. Top Shelf/ Knockabout Comics, 1999-2009.

Poore, Benjamin. "The Transformed Beast: Penny Dreadful, Adaptation, and the Gothic." Victoriographies, vol. 6, no. 1, 2016, pp. 62-81, DOI: https://doi.org/10.3366/vic.2016.0211. 
"Possession." Penny Dreadful, Season 1, Episode 7, written by John Logan, directed by James Hawes, Showtime, 2014.

Rocha, Lauren. "Angel in the House, Devil in the City: Explorations of gender in Dracula and Penny Dreadful." Critical Survey, vol. 28, no. 1, 2016, pp. 30-9, DOI: https://doi.org/10.3167/cs.2016.280104.

“There's No Place Like Plrtz Glrb." Angel, Season 2, Episode 22, written and directed D. Greenwalt, Warner Brothers, 2001.

“Through the Looking Glass." Angel, Season 2, Episode 21, written and directed by Tim Minear, Warner Brothers, 2001.

"Tomorrow." Angel, Season 3, Episode 22, written and directed by David Greenwalt, Warner Brothers, 2002.

Vint, Sherryl. "Whedon Studies after Whedon: A Conversation with Sherryl Vint." Slayage: The Journal of Whedon Studies, vol. 16, no. 2, 2018, pp. 176-91.

\section{Suggested Citation}

Tembo, Kwasu David. "The Curse and the Chora: The Double-Bind of the Choraic Conduit in Angel and Penny Dreadful." Alphaville: Journal of Film and Screen Media, no. 20, 2020, pp. 104118, DOI: https://doi.org/10.33178/alpha.20.08.

Kwasu David Tembo is a PhD graduate from the University of Edinburgh's Language, Literatures, and Cultures department. His research interests include, but are not limited to, comics studies, literary theory and criticism, philosophy, particularly the so-called "prophets of extremity"-Nietzsche, Heidegger, Foucault, and Derrida. He has published on Christopher Nolan's The Prestige in The Cinema of Christopher Nolan: Imagining the Impossible, edited by Jacqueline Furby and Stuart Joy (Columbia UP, 2015), and on Superman in Postscriptum: An Interdisciplinary Journal of Literary Studies (2017). 